\title{
Evaluation of Fuel Properties of Six Tropical Hardwood Timber Species for Briquettes
}

\author{
Stephen J. Mitchual1 ${ }^{*}$, Kwasi Frimpong-Mensah², Nicholas A. Darkwa² \\ ${ }^{1}$ Department of Construction and Wood Technology Education, University of Education, Winneba, Kumasi \\ Campus, Kumasi, Ghana \\ ${ }^{2}$ Department of Wood Science and Technology, Kwame Nkrumah University of Science and Technology, Kumasi, \\ Ghana \\ Email: "Stephen.mitchual@yahoo.com, Frimpongmensahk@yahoo.com, Nicdarkwa@yahoo.com
}

Received 1 January 2014; revised 31 January 2014; accepted 21 February 2014

Copyright (C) 2014 by authors and Scientific Research Publishing Inc.

This work is licensed under the Creative Commons Attribution International License (CC BY).

http://creativecommons.org/licenses/by/4.0/

(c) (i) Open Access

\section{Abstract}

The fuel potential of six tropical hardwood species namely: Triplochiton scleroxylon, Ceiba pentandra, Aningeria robusta, Terminalia superba, Celtis mildbreadii and Piptadenia africana were studied. Properties studied included species density, gross calorific value, volatile matter, ash content, organic carbon and elemental composition. Fuel properties were determined using standard laboratory methods. The result indicates that the gross calorific value (GCV) of the species ranged from 20.16 to $22.22 \mathrm{MJ} / \mathrm{kg}$ and they slightly varied from each other. Additionally, the GCV of the biomass materials were higher than that of other biomass materials like; wheat straw, rice straw, maize straw and sugar cane. The ash and volatile matter content varied from 0.6075 to $5.0407 \%$, and $75.23 \%$ to $83.70 \%$ respectively. The overall rating of the properties of the six biomass materials suggested that Piptadenia africana has the best fuel property to be used as briquettes and Aningeria robusta the worse. This study therefore suggests that a holistic assessment of a biomass material needs to be done before selecting it for fuel purpose.

\section{Keywords}

Ash Content; Briquette; Calorific Value; Elemental Composition; Species; Volatile Matter

\section{Introduction}

In line with the annual increase in demand for energy globally, energy demand in Ghana has increased significantly as a result of population increase and urbanization [1]. The availability of energy for domestic use in

${ }^{*}$ Corresponding author.

How to cite this paper: Mitchual, S.J., Frimpong-Mensah, K. and Darkwa, N.A. (2014) Evaluation of Fuel Properties of Six Tropical Hardwood Timber Species for Briquettes. Journal of Sustainable Bioenergy Systems, 4, 1-9. 
Ghana continues to pose a formidable challenge, especially with the high cost of cooking gas and kerosene. The increase in price of fossil fuels has resulted in increased consumption of wood fuel, particularly wood charcoal [1]. According to [1], as indicated in Table 1 the consumption of wood fuel in Ghana increased from 20,678,000 $\mathrm{m}^{3}$ in 2004 to 35,363,400 $\mathrm{m}^{3}$ in 2008, whilst the consumption of wood charcoal increased from $752,000 \mathrm{~m}^{3}$ to $1,477,700 \mathrm{~m}^{3}$ during the same period. Additionally, it was estimated by [2] that wood for use as firewood and for the production of charcoal will increase from an average value of 37,600,000 tonnes in 2008 to 58,700,000 tonnes by 2020.

Although consumption of biomass fuels like firewood and charcoal are themselves not bad, in that, they result in less damaging effect of the environment [3], this trend of shift in energy consumption towards firewood and charcoal would have serious consequence on the diminishing forest resources of Ghana. Besides, utilization of firewood and charcoal for cooking over open fires is highly inefficient in that it result in transfer of only 5\% - 10\% of the fuel's energy to the cooking pot [4]. The solution to this problem of increased reliance on firewood as domestic cooking fuels is the exploitation and development of biomass residue generated in Ghana. Biomass residue is generated in large quantities in Ghana annually and is available as a free, indigenous and environmentally friendly source of energy. It has been estimated that about 4,530,320 tonnes of agricultural residue was generated in Ghana in the year 2010 [5] [6]. Additionally, [7] indicated that about 142,080 $\mathrm{m}^{3}$ of sawdust was generated in Ghana in the year 2008. Sawdust and agricultural residues have become the most promising choice as cooking fuels due to their availability in substantial quantities as waste annually [4]. A study conducted by [8] indicated that the fuel properties of sawdust of tropical hardwood species could be significantly enhanced through the application of densification technology at room temperature $\left(28^{\circ} \mathrm{C}\right)$ using low compacting pressure (10 - $50 \mathrm{MPa}$ ). Similar study indicated that a combination of agricultural waste materials like maize cobs and sawdust of low density species could significantly improve the physical and mechanical properties of briquettes produced from maize cobs [9]. However, for the efficient utilization of biomass residue as domestic and Industrial fuel, they have to be characterized. According to [10] [11], the fuel properties of wood can be summarized by their elemental and proximate analyses and determination of heating value. These fuel properties include species density, calorific value, volatile matter, nitrogen, hydrogen, sulphur, arsenic, cadmium, copper and lead content of the raw material. Comparison of burning characteristics and some chemical elements in biomass materials show that the composition of samples varies considerably. Since briquettes can be made from wide varieties of biomass residues, selection of the best material for making briquettes has to be made based on the one that has better fuel properties or positive fuel attributes [4]. Thus, this study which forms part of a broader research on briquetting characteristics of sawdust of six tropical hardwood species sought to investigate the fuel properties of sawdust of six species frequently sawn in Ghanaian sawmills.

\section{Materials and Methods}

\subsection{Materials and Material Preparation}

Sawdust and wood samples from the following tropical hardwood species: Triplochiton scleroxylon, Ceiba pentandra, Aningeria robusta, Terminalia superba, Celtis mildbreadii and Piptadenia africana were used for the study. The sawdust was sun dried at an average relative humidity and environmental temperature of $75 \%$ and

Table 1. Consumption of wood fuel and wood charcoal in Ghana from 2004-2008.

\begin{tabular}{ccc}
\hline Year & Wood fuel $\left(\mathrm{m}^{3}\right)$ & Wood charcoal $(\mathrm{t})$ \\
\hline 2004 & $20,678,000$ & 752,000 \\
2005 & $20,678,000$ & 752,000 \\
2006 & $33,039,530$ & $1,358,977$ \\
2007 & $31,477,900$ & $1,418,300$ \\
2008 & $35,363,400$ & $1,477,700$ \\
Total & $141,236,830$ & $5,758,977$ \\
\hline
\end{tabular}

Source: [1]. 
$28^{\circ} \mathrm{C}$ respectively for between 5 to 7 days.

\subsection{Density of Timber Species}

Densities of the six timber species from which sawdust was collected for the study were determined in accordance with [12]. Fifteen clear specimens with dimensions $20 \mathrm{~mm} \times 20 \mathrm{~mm} \times 30 \mathrm{~mm}$ were prepared for each species. The oven-dried masses of the specimens were determined. Thereafter, they were dipped one by one in a paraffin wax and then kept in a desiccator. The volume displacement method which employs the use of Eureka can and a measuring cylinder was used to determine the volumes of the specimen. The density of each specimen was then computed as:

$$
\text { Density }=\frac{\text { Mass of specimen }}{\text { Volume of specimen }}
$$

\subsection{Gross Calorific Value}

The gross calorific value of the samples of biomass materials was determined in accordance with [13]. This was done using an adiabatic bomb calorimeter. About $0.4 \mathrm{~g}$ of each sample was burnt in the bomb calorimeter until complete combustion was obtained. The difference between the maximum and minimum temperatures obtained was used to compute the gross calorific values of the biomass materials as follows:

$$
\mathrm{Q}=\frac{\left(\mathrm{C}_{\text {water }}+\mathrm{C}_{\text {cal }}\right)\left(\mathrm{T}_{2}-\mathrm{T}_{1}\right)^{\circ} \mathrm{C}}{\mathrm{W}_{\mathrm{f}}}
$$

Where:

$\mathrm{Q}=$ Calorific value of species $(\mathrm{kJ} / \mathrm{kg})$

$\mathrm{W}_{\mathrm{f}}=$ Weight of the biomass material sample $(\mathrm{kg})$

$\mathrm{C}_{\text {cal }}=$ Heat capacity of the bomb calorimeter

$\mathrm{T}_{2}-\mathrm{T}_{1}=$ Rise in temperature

$\mathrm{C}_{\text {water }}=$ Heat capacity of water

\subsection{Proximate Analysis}

\subsubsection{Percentage (\%) Ash Content (PAC)}

PAC of the biomass materials was determined in accordance with [14]. This was done by heating approximately $2 \mathrm{~g}$ of oven-dried mass of each biomass material with particle size of $425 \mu \mathrm{m}$, in an electric furnace at a temperature of $600^{\circ} \mathrm{C}$ for four hours. Thereafter, it was cooled in a desiccator and weighed to represent the ash content of the sample. The percentage ash content was calculated as follows:

$$
\operatorname{Ash} \operatorname{content}(\%)=\frac{M_{\text {ash }}}{M_{\text {over-dry }}} \times 100
$$

Where $M_{\text {ash }}$ is the mass of the ash and $M_{\text {oven-dry }}$ is the mass of oven-dried sample.

\subsubsection{Percentage (\%) Volatile Matter}

The percentage volatile matter of the biomass materials was determined in accordance with [15]. Approximately $2 \mathrm{~g}$ of each of the biomass materials, particle size $425 \mu \mathrm{m}$, was placed in a porcelain crucible. Each sample was first oven-dried and then kept in a furnace at a temperature of $550^{\circ} \mathrm{C}$ for $10 \mathrm{~min}$ and weighed after cooling in a desiccator. The percentage volatile matter was then calculated as follows:

$$
\text { Percentage volatile matter }(\%)=\frac{A-B}{A} \times 100
$$

Where $A$ is the weight of the oven-dried sample and $B$ is the weight of the sample after $10 \mathrm{~min}$ in the furnace at $550^{\circ} \mathrm{C}$.

\subsubsection{Percentage (\%) Organic Carbon (POC)}

POC content of the biomass materials was determined using [14] [16]. This was done by subtracting the mass (g) 
of ash from the oven-dry mass of the sample to obtain the mass (g) of organic matter component. The percentage organic carbon content was then estimated as follows:

$$
\text { Organic carbon content }(\%)=\frac{M_{\text {organic matter }} * 0.58}{M_{\text {oven-dry }}} \times 100
$$

Where $M_{\text {organic matter }}$ is mass of organic matter and $M_{\text {oven-dry }}$ is the mass of oven-dried sample.

\subsection{Ultimate Analysis}

The important chemical constituents of the biomass materials namely: nitrogen, sulphur, hydrogen, arsenic, cadmium, copper and lead were determined through ultimate analysis. The nitrogen content of the samples was determined using the Kjeldahl method for quantitative determination of nitrogen in chemical substances [17]. The sulphur content was determined by turbidimetric method [17]. The hydrogen content was determined using exchangeable acidity titrimetric method [18]. The arsenic, cadmium, copper and lead content of the biomass materials were determined by wet digestion followed by estimation of element in the resulting solution using atomic absorption spectroscopy method [19].

\section{Results and Discussions}

\subsection{Fuel Characteristics of Six Tropical Hardwood Timber Species}

\subsubsection{Wood Density}

The density of biomass material plays an important role in the determination of its fuel value. Denser wood contains more heat per unit volume in that they tend to burn for longer periods of time. In Table 2 column 2 is showed the densities of six hardwood species used for this study. The density of the species ranged from 409.22 $\mathrm{kg} / \mathrm{m}^{3}$ (C. pentandra) to $764.11 \mathrm{~kg} / \mathrm{m}^{3}$ (C. mildbreadii). This result therefore suggest that C. mildbreadii is more likely to have a higher energy per unit volume than the other species, in that, all things being equal it will burn for a longer period of time than the other species. Additionally, in the area of densification, the density of timber species was found to have a significant negative correlation with the compressive strength in cleft, impact resistance index and water resistance quality of briquettes produced at room temperature $\left(28^{\circ} \mathrm{C}\right)$ using low compacting pressure (10 - $50 \mathrm{MPa})$ [20]. Besides, species with higher densities are likely to produce briquettes with higher densities when the biomass material is pressed at room temperature $\left(28^{\circ} \mathrm{C}\right)$ using low compacting pressure [20]. Therefore, briquettes produced from low density wood species (C. pentandra) at room temperature using low compacting pressure is likely to produce briquettes with higher mechanical properties but lower density than that produced from higher density wood species.

\subsubsection{Calorific Value}

The standard measure of the energy content of a fuel is its heating value or calorific value. In the second column

Table 2. Fuel properties of six tropical hardwood species and, Austria and Germany standards for fuel pellets.

\begin{tabular}{ccccccccc}
\hline Species & $\begin{array}{c}\text { Wood density } \\
\left(\mathbf{k g} / \mathbf{m}^{\mathbf{3}}\right)\end{array}$ & $\begin{array}{c}\text { Gross calorific } \\
\text { value } \mathbf{( M J} / \mathbf{k g})\end{array}$ & $\begin{array}{c}\text { Volatile matter } \\
\mathbf{( \% )}\end{array}$ & $\begin{array}{c}\text { Ash content } \\
\mathbf{( \% )}\end{array}$ & $\begin{array}{c}\text { Organic } \\
\text { carbon (\%) }\end{array}$ & N (\%) & H (\%) & S (\%) \\
\hline C. pentandra & 409.22 & 20.33 & 82.43 & 4.7248 & 55.26 & 0.4817 & 5.30 & 0.0458 \\
T. scleroxylon & 450.62 & 21.60 & 80.97 & 2.0119 & 56.83 & 0.5600 & 4.08 & 0.0919 \\
A. robusta & 572.64 & 20.89 & 75.23 & 5.0407 & 55.08 & 0.4813 & 3.83 & 0.2142 \\
T. superba & 570.08 & 22.22 & 79.64 & 2.9574 & 56.29 & 0.6213 & 3.88 & 0.0561 \\
P. africana & 744.89 & 22.17 & 80.60 & 0.6075 & 57.65 & 0.7133 & 4.20 & 0.0475 \\
C. mildbreadii & 764.11 & 20.16 & 83.70 & 3.7077 & 55.85 & 0.6917 & 4.21 & 0.0572 \\
Austria ÖNORM M7135 & & $\geq 18.0$ & & $<6.0$ & - & $\leq 0.6$ & $\leq 0.08$ \\
Germany DIN 51731/DINplus & & $17.5-19.5$ & & $<1.5 \%$ & - & $<0.3$ & $<0.08$ \\
\hline
\end{tabular}

Source of information for national standards for fuel pellets (Austria and Germany): [21]. 
of Table 2 is presented the gross calorific value (GCV) of the six tropical hardwood species used for the study. The least GCV of the species studied was $20.16 \mathrm{MJ} / \mathrm{kg}$ (C. mildbreadii) whilst the highest was $22.22 \mathrm{MJ} / \mathrm{kg}$ ( $T$. superba). The GCV of the species studied could be considered adequate since they are greater than the minimum values suggested by the Austria and German standards for fuel pellets and briquettes (Austria ÖNORM M7135, Calorific value $\geq 18.0$ MJ/kg; Germany DIN 51731/DINplus, Calorific value 17.5 - $19.5 \mathrm{MJ} / \mathrm{kg}$ ). Additionally, the GCV of all the species studied were higher than that suggested by [22] [23] for woody biomass. In a study on fuel characteristics of wood and bark and factors affecting heat recovery, [22] concluded that woody biomass has an average heating density of $19.8 \mathrm{MJ} / \mathrm{kg}$. The heating values of the species studied, besides being higher than that of other woody biomass were greater than that of other biomass fuels like: wheat straw $=17.51$ $\mathrm{MJ} / \mathrm{kg}$; rice straw $=14.56 \mathrm{MJ} / \mathrm{kg}$; maize straw $=17.70 \mathrm{MJ} / \mathrm{kg}$ and sugarcane bagasse $=17.33 \mathrm{MJ} / \mathrm{kg}$ [24]. Even though the species studied comparatively had higher heating values, their heating values were lower than that of fossil fuels like kerosene (46.5 MJ/kg), natural gas (37.3 MJ/kg) and hard coal (31.80 MJ/kg) [25]. In spite of the lower heating values of the biomass fuels studied compared to that of fossil fuels they would increasingly continue to be an important source of energy because of their long term sustainability as a source of energy as well as their enormous social and environmental benefits.

\subsubsection{Volatile Matter}

Volatile matter refers to the part of a biomass material that is released as volatile gases when it is heated up to $400^{\circ} \mathrm{C}$ to $500^{\circ} \mathrm{C}$. Biomass generally has high volatile matter content of around $70 \%$ to $86 \%$ and low char content. The high volatile matter content of a biomass material indicates that during combustion, most of it will volatise and burn as gas in the cookstove [26]. The volatile matter of the six wood species studied varied from 75.23\% (A. robusta) to $83.70 \%$ (C. mildbreadii). With the exception of A. robusta, the volatile matter of all the species studied was greater than $78 \%$. According to [27] biomass materials with volatile contents up to $78 \%$ indicated ignition temperatures between $236^{\circ} \mathrm{C}$ and $270^{\circ} \mathrm{C}$, while the lignite with volatile content $53 \%$ ignited at $274^{\circ} \mathrm{C}$.

\subsubsection{Ash Content}

Ash deposit on heat transfer surfaces in boilers and internal surfaces in gasifiers accelerate corrosion of hot heat exchanging tubes and also reduce their efficiency [28]. The ash content (column 5 of Table 2) of the sawdust of the species studied varied from $0.6075 \%$ (P. africana) to $5.0407 \%$ (A. robusta). The high ash content of A. robusta indicates that the species has high mineral matter. The ash content of all the species studied was lower than $6 \%$, that is, the value beyond which the ash content of the biomass fuel is considered not adequate according to the Austria ÖNORM M7135 as cited in [21]. With the exception of A. robusta and C. mildbreadii which had comparatively higher percentage ash content, all the other species had ash content less than $4 \%$, the level beyond which slagging of ash usually would occur with biomass fuels [28]. Thus, it is likely that when sawdust of species like P. africana, T. scleroxylon, T. superba and C. mildbreadii are used as fuel no slagging would occur. On the contrary, slagging may occur when A. robusta and C. pentandra are used as biomass fuel.

\subsubsection{Organic Carbon, Nitrogen, Hydrogen and Sulphur Content of Six Tropical Hardwood Species} Indicated in Table 2, columns 6, 7, 8 and 9 are the organic carbon, nitrogen, hydrogen and sulphur content of the species studied. The organic carbon content of the biomass materials ranged from $55.26 \%$ for $C$. pentandra to $57.65 \%$ for $P$. Africana. Fixed carbon gives a rough estimate of the heating value of a fuel and acts as the main heat generator during burning [26]. Thus, the higher the carbon content of a biomass fuel the more likely that the species would have higher heating value. The nitrogen content of the species studied ranged from $0.4813 \%$ (A. robusta) to $0.7133 \%$ (P. africana). Nitrogen content is a good indicator of the amount of nitrogenbased toxic components that can be formed during combustion. During combustion of wood fuel, nitrogen is oxidized into nitrogen oxide $\left(\mathrm{NO}_{\mathrm{X}}\right)$. When emitted from combustion facilities at relatively low levels, $\mathrm{NO}_{\mathrm{X}}$ may have a useful fertilizing effect on forests. However, as emission levels increase, $\mathrm{NO}_{\mathrm{x}}$ produces adverse health effects and increases the acidification of water and soils [29]. Exposure to nitrogen oxides increases the risk of respiratory infections as it is highly toxic and irritating to the respiratory system [30]. When $\mathrm{NO}_{\mathrm{X}}$ and volatile organic compounds react in the presence of sunlight, they form a photochemical smog, which is a significant form of air pollution [30]. The nitrogen content of A. robusta (0.4813\%), C. pentandra $(0.4817 \%)$ and $T$. scleroxylon $(0.5600 \%)$ are lower than the limit set by the Austria national standard for pellet and briquettes, Austria 
ÖNORM M7135 (i.e. Nitrogen content $\leq 0.6 \%$ ) but higher than the limit set by the German national standard for fuel pellet, Germany DIN 51731/DINplus (i.e. Nitrogen content $\leq 0.3 \%$ ). However, the nitrogen content of $T$. superba $(0.6213 \%)$, C. mildbreadii $(0.6917 \%)$ and P. africana $(0.7133 \%)$ were higher than the limits set by both the Austria and German standards for fuel pellet and briquettes.

Hydrogen is the third major constituent of the organic component in biomass. Typically, it comprises $5 \%$ to $6 \%$ of the biomass dry matter. A higher hydrogen content leads to a higher heating value [31]. The hydrogen content of the species studied ranged from $3.83 \%$ (C. pentandra) to $5.30 \%$ (A. robusta). With the exception of $C$. pentandra, the hydrogen content of the species studied were below the expected range of $5 \%$ to $6 \%$. Sulphur emissions from combustion of fuels cause extensive damage to ecosystems and buildings. As with nitrogen, sulphur is oxidized during combustion to form sulphur oxide $\left(\mathrm{SO}_{\mathrm{X}}\right)$. This compound can have serious environmental effects and can cause acidification of soils and water [29]. The sulphur content of the species studied ranged from $0.0458 \%$ (C. pentandra) to $0.2142 \%$ (A. robusta). The sulphur content of C. pentandra, P. africana, T. superba and C. mildbreadii were lower than the limits set by the Austria and German national standards for fuel pellet and briquettes (Sulphur content $\leq 0.08 \%$ ). However, T. scleroxylon and A. robusta had sulphur contents more than the limits set by the Austria and German national standards for fuel pellet and briquettes. This means that it is likely that when sawdust $T$. scleroxylon and A. robusta are used for making fuel briquettes they, would emit sulphur compounds more than the accepted limits into the atmosphere. This would have adverse effects on both the environment and human health.

\subsubsection{Toxic Metals in Selected Wood Species}

All biomass fuels contain heavy or toxic metals to some degree. The composition of these toxic metals varies from species to species. Figures 1 and 2 show the composition of copper, lead, arsenic and cadmium in the biomass materials studied as well as the German standard for pellet and briquettes for these metals. The composition of copper ranged from $6.07 \mathrm{mg} / \mathrm{kg}$ for $T$. scleroxylon to $8.03 \mathrm{mg} / \mathrm{kg}$ for both $T$. superba and A. robusta. Additionally, the lead content of the biomass materials ranged from $0.40 \mathrm{mg} / \mathrm{kg}$ (P. africana) to $5.67 \mathrm{mg} / \mathrm{kg}$ ( $T$. superba). The levels of copper in the species studied were higher than the maximum value of $5 \mathrm{mg} / \mathrm{kg}$ recommended by the German standard for biomass pellets and briquettes. On the contrary, the amount of lead in the species considered were lower than the maximum value of $10 \mathrm{mg} / \mathrm{kg}$ recommended by German standard for biomass pellets and briquettes [21]. Arsenic composition in the six biomass materials also ranged from 0.13 $\mathrm{mg} / \mathrm{kg}$ (P. africana) to $0.97 \mathrm{mg} / \mathrm{kg}$ for A. robusta, whilst that of cadmium ranged from $0.33 \mathrm{mg} / \mathrm{kg}$ (C. pentandra) to $0.95 \mathrm{mg} / \mathrm{kg}$ ( $T$. superba). These values are significantly higher than the maximum values recommended by the German standard for fuel briquettes and pellet. Heavy metals in wood are noted to have adverse effects on human health as well as the environment. Prolonged exposure to heavy metals such as cadmium, copper, lead,

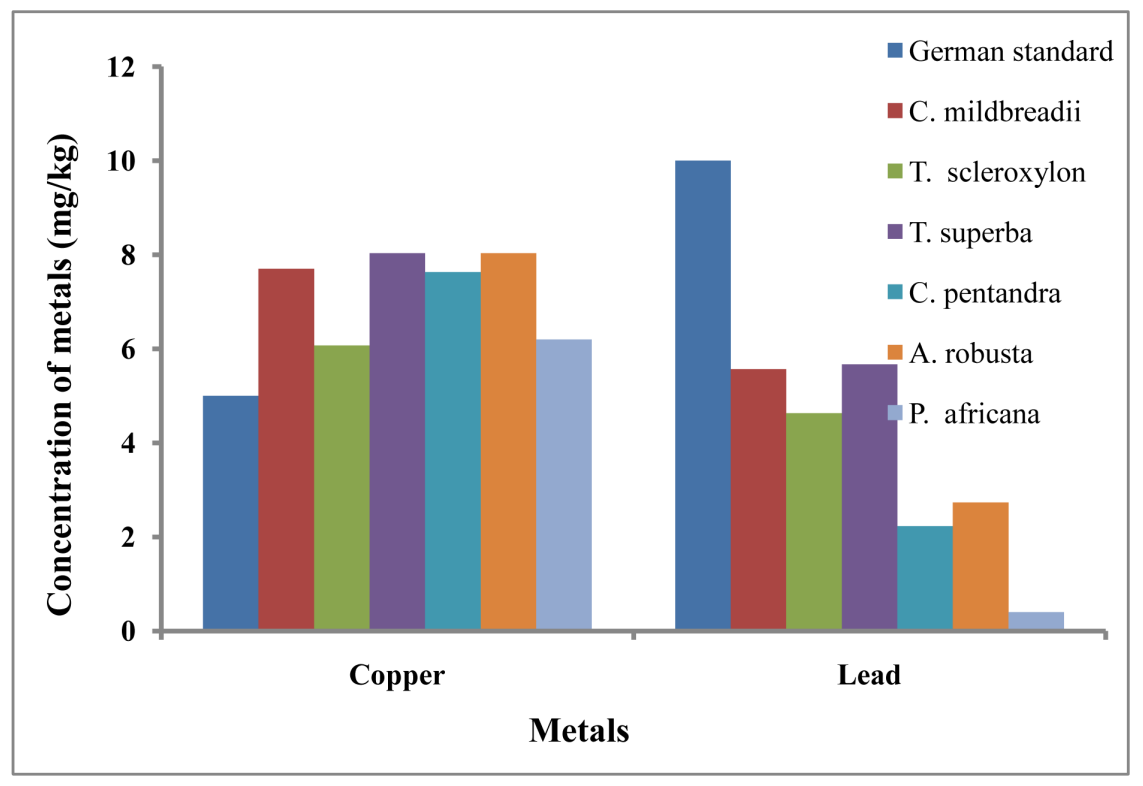

Figure 1. Concentration of copper and lead in sawdust of six tropical hardwood species. 
nickel and zinc can cause deleterious health effects in humans [32].

\subsection{Rating of Fuel Properties of Six Tropical Hardwood Species}

Table 3 indicates the ratings of fuel properties of the six hardwood species used for the studies. Each propertywas assigned a value between 1 and 6 , with 1 being the best and 6 being the worst. The overall rating was the mean rating of all the properties measured for each species [33]. The ratings suggest that sawdust from $P$. africana has the best fuel properties (2.25) and the worst is A. robusta (4.50). Even though C. pentandra was fifth in

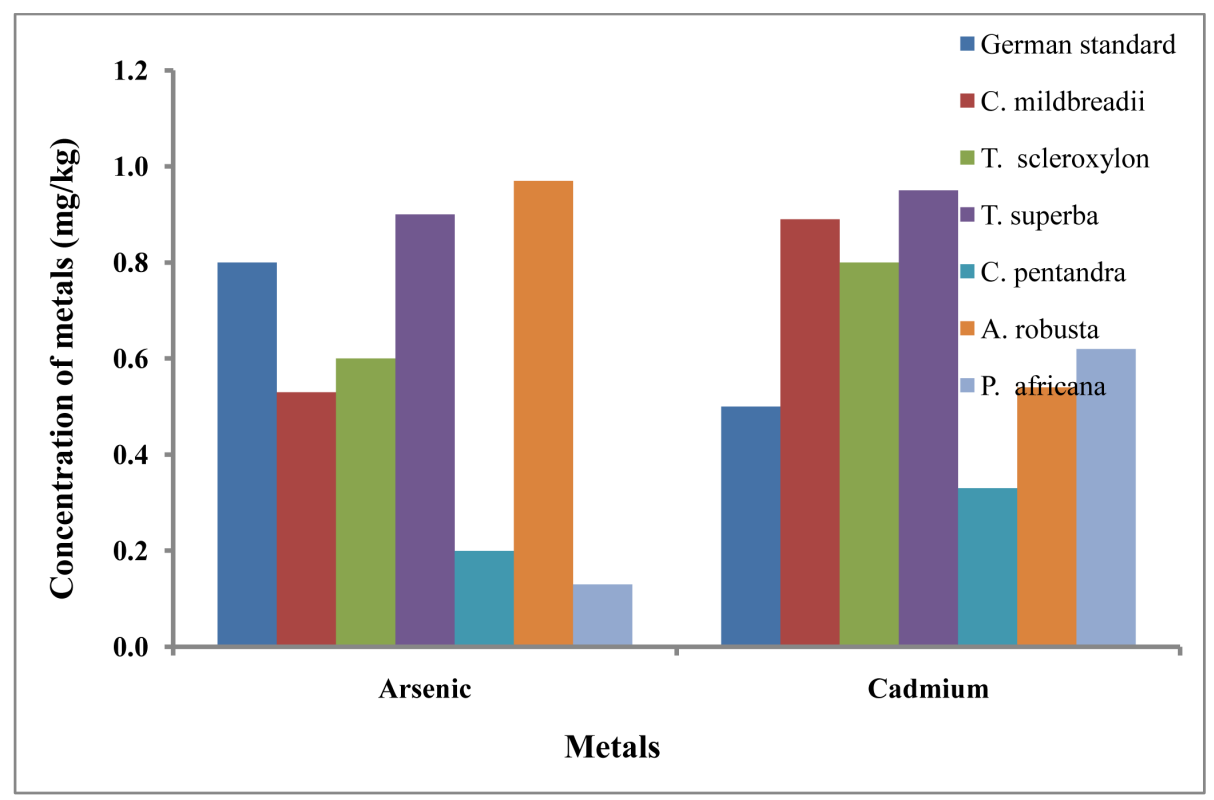

Figure 2. Concentration of arsenic and cadmium in sawdust of six tropical hardwood species.

Table 3. Rating of fuel properties of six tropical hardwood species ( $1=$ best, 6 = worst).

\begin{tabular}{|c|c|c|c|c|c|c|}
\hline \multirow{2}{*}{ Property } & \multicolumn{6}{|c|}{ Species } \\
\hline & Ceiba pentandra & $\begin{array}{l}\text { Triplochiton } \\
\text { scleroxylon }\end{array}$ & $\begin{array}{c}\text { Aningeria } \\
\text { robusta }\end{array}$ & Terminalia superba & Piptadenia africana & Celtis mildbreadii \\
\hline Wood density & 6 & 5 & 3 & 4 & 2 & 1 \\
\hline Calorific value & 5 & 3 & 4 & 1 & 2 & 6 \\
\hline Volatile matter & 2 & 3 & 6 & 5 & 4 & 1 \\
\hline Ash & 5 & 2 & 6 & 3 & 1 & 4 \\
\hline Carbon & 5 & 2 & 6 & 3 & 1 & 4 \\
\hline Nitrogen & 2 & 3 & 1 & 4 & 6 & 5 \\
\hline Sulphur & 1 & 5 & 6 & 3 & 2 & 4 \\
\hline $\mathrm{Cu}$ & 3 & 2 & 5 & 6 & 1 & 4 \\
\hline AS & 2 & 4 & 6 & 5 & 1 & 3 \\
\hline $\mathrm{Pb}$ & 2 & 4 & 3 & 6 & 1 & 5 \\
\hline $\mathrm{Cd}$ & 1 & 4 & 2 & 6 & 3 & 5 \\
\hline $\mathrm{H}$ & 1 & 4 & 6 & 5 & 3 & 2 \\
\hline Rating (Average) & 2.92 & 3.42 & 4.50 & 4.25 & 2.25 & 3.67 \\
\hline
\end{tabular}


the rating of the calorific value of the species, the overall rating indicated that it has the second best fuel properties. The above result suggest that calorific value should not be the single factor to be used to determine the suitability of a biomass material for fuel briquettes. Other factors such as those studied which have effect on burning characteristics and also impact the environment need to be considered.

\section{Conclusion}

This study assessed the fuel properties of six tropical hardwood species. It can be concluded from the results that all the species studied had adequate gross calorific value ranging from 20.16 to $22.22 \mathrm{MJ} / \mathrm{kg}$. Besides, the ash content of the biomass materials ranged from $0.6075 \%$ to $5.0407 \%$. This value is lower than $6 \%$, that is, the value beyond which the ash content of the biomass fuel is considered not adequate according to the Austria standard for fuel pellet and briquettes. The results further indicated that Piptadenia africana has the best fuel property with fuel rating of 2.25 and Aningeria robusta the worse with fuel rating of 4.50. It could further be concluded from the study that, an assessment of fuel properties of biomass materials need to be done holistically taking into consideration all the factors that will impact on the energy value and environment as well as health issues.

\section{Acknowledgements}

The authors are grateful to the Civil Engineering Department of the Kwame Nkrumah University of Science and Technology, Kumasi, Ghana and Forest Research Institute of Ghana for providing laboratory support for this study. Special thanks also go to Miss Agnes Ankomah of the Crops Research Institute of Ghana for providing statistical software for this research work.

\section{References}

[1] Duku, M.H., Gu, S. and Hagan, E.B. (2011) A Comprehensive Review of Biomass Resources and Biofuels Potential in Ghana. Renewable and Sustainable Energy Reviews, 15, 404-415. http://dx.doi.org/10.1016/j.rser.2010.09.033

[2] Energy Commission (2006) Strategic National Energy Plan 2006-2020—Energy Supply to the Economy. http://energycom.gov.gh/files/snep/WOOD\%20FUEL\%20final\%20PD.pdf

[3] Nendel, K., Clauss, B. and Böttger, U. (1998) The Preconditioning of Biomass by Briquetting Technology and the Influence on the Combustion Behaviour. The 10th European Conference on Biomass for Energy and Industry, Würzburg, 8-11 June 1998, 1287-1290.

[4] Oladeji, J.T. (2010) Fuel Characterization of Briquettes Produced from Corncob and Rice Husk Resides. The Pacific Journal of Science and Technology, 11, 101-106.

[5] FAOSTAT (2010) Crop Production in Ghana in 2010. Food and Agriculture Organisation of the UN, Rome. http://faostat.fao.org/site/339/default.aspx

[6] OECD/IEA (2010) Sustainable Production of Second-Generation Biofuels, Potential and Perspectives in Major Economies and Developing Countries. Information Paper, Paris. http://www.iea.org/publications/freepublications/publication/biofuels_exec_summary.pdf

[7] ITTO (2008) Annual Review and Assessment of the World Timber Situation. International Tropical Timber Organisation.

[8] Mitchual, S.J., Frimpong-Mensah, K. and Darkwa, N.A. (2013) Effect of Species, Particle Size and Compacting Pressure on Relaxed Density and Compressive Strength of Fuel. International Journal of Energy and Environmental Engineering, 4, 6 p. http://dx.doi.org/10.1186/2251-6832-4-30

[9] Mitchual, S.J., Frimpong-Mensah, K., Darkwa, N.A. and Akowuah, J.O. (2013) Briquettes from Combination of Maize Cobs and Ceiba pentandra at Room Temperature and Low Compacting Pressure without a Binder. International Journal of Energy and Environmental Engineering, 4, 7 p. http://dx.doi.org/10.1186/2251-6832-4-38

[10] Demirbas, T. and Demirbas, C. (2009) Fuel Properties of Wood Species. Energy Sources, 31, 1464-1472. http://dx.doi.org/10.1080/15567030802093153

[11] Saravanan, V., Parthiban, K.T., Kumar, P., Anbu, P.V. and Ganesh, P.P. (2013) Evaluation of Fuel Wood Properties of Melia dubia at Different Age Gradation. Research Journal of Agriculture and Forestry Sciences, 1, 8-11.

[12] ASTM International (2008) ASTM standard D2395-2007a: Standard Test Methods for Specific Gravity of Wood and 
Wood-Based Materials. ASTM International, West Conshohocken.

[13] ASTM International (2012) ASTM Standard E711-87, Standard Test Method for Gross Calorific Value of Refuse-Derived Fuel by the Bomb Calorimeter. http://ia600806.us.archive.org/23/items/gov.law.astm.e711.1987/astm

[14] ASTM International (2008) ASTM D 1102-84, Test Method for Ash in Wood. Annual Book of ASTM Standards, 153-154.

[15] ASTM International (2008) ASTM D3175-11, Standard Test Method for Volatile Matter in the Analysis Sample of Coal and Coke. Annual Book of ASTM Standards, 153-154.

[16] (2008) FAO Guide to Laboratory Test.

[17] Motsara, M.R. and Roy, N.R. (2008) Guide to Laboratory Establishment for Plant Nutrient Analysis. 19th Edition, FAO, Rome, 42-88.

[18] Mclean, E.O. (1965) Aluminium in Methods of Soil Analysis. America Science Agronomy, Madison, Wisconsin, 978-998.

[19] Horwitz, W. and Latimer, G.W. (2005) Official Methods of Analysis of AOAC International. 18th Edition, Association of Official Analytical Chemistry International, Maryland.

[20] Mitchual, S.J. (2013) Densification of Sawdust of Tropical Hardwoods and Maize Cobs at Room Temperature Using Low Compacting Pressure without a Binder. Ph.D. Thesis, School of Graduate Studies, Kwame Nkrumah University of Science and Technology, Kumasi.

[21] Hahn, B. (2004) Existing Guidelines and Quality Assurance for Fuel Pellets-Pellets for Europe Project. UMBERA, Umweltorientierte Betriebsberatungs-, Forschungs- und Entsorgungs-Gesellschaft m.b.H.

[22] Corder, S.E. (1976) Fuel Characteristics of Wood and Bark and Factors Affecting Heat Recovery. USDA Forest Products Laboratory, Madison.

[23] Stahl, R., Henrich, E., Gehrmann, H.J., Vodegel, S. and Koch, M. (2004) Definition of a Standard Biomass. RENEW-Renewable Fuels for Advanced Power Trains.

[24] Ebeling, J.M. and Jenkins, B.M. (1985) Physical and Chemical Properties of Biomass Fuels. Transaction of the ASAE, 28, 898-902. http://dx.doi.org/10.13031/2013.32359

[25] Payne, G.A. (1980) The Energy Managers Handbook. Westbury House, Guildford.

[26] Akowuah, J.O., Kemausuor, F. and Mitchual, S.J. (2012) Physico-Chemical Characteristics and Market Potential of Sawdust Charcoal Briquettes. International Journal of Energy and Environmental Engineering, 3, 6 p. http://dx.doi.org/10.13031/2013.32359

[27] Vamvuka, D., Chatib, N.E. and Sfakiotakis, S. (2011). Proceedings of the European Combustion Meeting, Cardiff, 28 June-1 July 2011.

[28] Grover, P.D. and Mishra, S.K. (1996) Biomass Briquetting: Technology and Practice. Regional Wood Energy Development Programme in Asia. Field Document No. 46, Food and Agricultural Organization.

[29] Extension (Unpublished) Woody Biomass Properties. www.extension.org/pages/26517/woody-biomass.properties

[30] Sillman, S. (2003) Tropospheric Ozone and Photochemical Smog. In: Sherwood Lollar, B., Ed., Treatise on Geochemistry, Environmental Geochemistry, Vol. 9, Ch. 11, Elsevier. http://www.TreatiseOnGeochemistry.com

[31] Jenkins, B.M., Baxter, L.L., Miles Jr., T.R. and Miles, T.R. (1998) Combustion Properties of Biomass. Fuel Processing Technology, 54, 17-46. http://dx.doi.org/10.1016/S0378-3820(97)00059-3

[32] Singh, R., Gautam, N., Mishra, A. and Gupta, R. (2011) Heavy Metals and Living Systems: An Overview. Indian Journal of Pharmacology, 43, 246-253. http://dx.doi.org/10.4103/0253-7613.81505

[33] Abbot, P., Lowore, J., Khofi, C. and Werren, M. (1997) Defining Firewood Quality: A Comparison of Quantitative and Rapid Appraisal Techniques to Evaluate Firewood Species from a Southern African Savannah. Biomass and Bioenergy, 12, 429-437. http://dx.doi.org/10.1016/S0961-9534(96)00084-0 